DOI 10.7764/rcia.v45i1.1841

\title{
Effect of daily herbage allowance restriction on pasture characteristics and milk production by grazing dairy cows in spring
}

\author{
Verónica Merino ${ }^{1,2}$, Oscar Balocchi ${ }^{3}$, and Rubén Pulido ${ }^{4}$ \\ 'Universidad Austral de Chile, Faculty of Agricultural Sciences, Graduate School. Valdivia, Chile, PO Box \\ 567, Valdivia, Chile. \\ ${ }^{2}$ Universidad de Concepción, Faculty of Agronomy, Department of Animal Production. Concepción, Chile \\ ${ }^{3}$ Universidad Austral de Chile, Faculty of Agricultural Sciences, Institute of Animal Production. PO Box \\ 567, Valdivia, Chile \\ ${ }^{4}$ Universidad Austral de Chile, Faculty of Veterinary Sciences, Institute of Animal Science. PO Box 567, \\ Valdivia, Chile
}

\begin{abstract}
V. Merino, O. Balocchi, and R. Pulido. 2018. Effect of daily herbage allowance restriction on pasture characteristics and milk production by grazing dairy cows. Cien. Inv. Agr. 45(1): 21-34. The cumulative effects of daily herbage allowance (DHA) restriction on pasture characteristics and the sustainability of pasture-based dairy systems were evaluated. Sixty-four dairy cows were randomly assigned to one of two grazing treatments (20 and $30 \mathrm{~kg} \mathrm{DM} \mathrm{cow}^{-1}$ day $\left.^{-1}\right)$. Milk yield and pre- and post-grazing herbage mass were recorded for every grazing event. Botanical and chemical compositions of the pasture were evaluated. Low DHA increased the stocking rate by 0.7 cows ha ${ }^{-1}$ and consequently increased grazing efficiency from 41 to $47 \%$. Daily herbage allowance restriction did not affect pasture characteristics or milk production per cow, but DHA restriction increased milk production per hectare $(+27 \%)$. The results suggest that restriction on daily herbage allowance ensures a higher level of herbage utilization and milk output per ha than high DHA, without affecting pasture characteristics. Therefore, DHA might be a useful grazing management tool for improving the profitability and sustainability of grazing-based dairy systems.
\end{abstract}

Keywords: Dairy systems, grazing management, milk yield, pasture utilization, sustainability.

\begin{abstract}
Abbreviations used: ADF (acid detergent fiber); BCS (body condition score); BW (body weight); CP (crude protein); DM (dry matter); DMI (dry matter intake); DHA (daily herbage allowance); K (potassium); ME (metabolizable energy); N (nitrogen); NDF (neutral detergent fiber); P (phosphorous); SR (stocking rate); WSC (water-soluble carbohydrates).
\end{abstract}

\section{Introduction}

The abundance of pasture-based dairy systems is primarily due to their low cost of production

Received Aug 22, 2017. Accepted Mar 21, 2018. Corresponding author: obalocch@uach.cl
(Peyraud and Delaby, 2001), and they are more cost effective than indoor concentrate-based systems (Peyraud et al., 1996). The success of grazing-based dairy systems, in the medium to long term, depends on the efficient use of pasture and the production of high milk output per hectare. However, the low efficiency of pasture 
harvest through grazing limits the profitability and sustainability of milk production systems (Dillon et al., 2008). Consequently, one of the greatest challenges for an efficient grazing-system is understanding the underlying effect of DHA on the physiology and quality of the pasture and on the productivity of dairy production systems. This knowledge could contribute to maximizing the grazing efficiency and milk production per hectare, without penalizing the sustainability of dairy production systems.

Daily herbage allowance is a grazing practice defined as the quantity of daily herbage offered per cow above a specified height (Roca-Fernandez et al., 2012). It depends on pre-grazing herbage mass (Pérez-Prieto and Delagarde, 2013), and it is proportionate to the stocking rate (SR) because as DHA increases, the stocking rate decreases (Tozer et al., 2004).

Studies have focused on identifying the effect of DHA on herbage intake and animal performance (Peyraud et al., 1996; Dalley et al., 1999; Bargo et al., 2002; Kennedy et al., 2007; McEvoy et al., 2008; McCarthy et al., 2011). However, how the restriction of daily herbage allowance influences the pasture characteristics and sustainability of pasture-based dairy systems in the long-term has not yet been fully evaluated.

High DHA might have negative impacts on the herbage quality of the following grazing rotations due to increases in the amount of refused pasture (Stakelum et al., 2007). Selecting adequate levels of daily herbage allowance to enhance herbage utilization and milk output per hectare could improve the sustainability and profitability of dairy systems in the long term.

The aim of the study was to examine the influence of the cumulative effects of DHA restrictions on grazing management parameters, pasture nutritive quality levels, dynamics of pasture depletion and milk performance of dairy cows in spring.

\section{Materials and methods}

This study was conducted as part of a larger study, which was undertaken at the Vista Alegre Experimental Research Station of the Universidad Austral de Chile, Valdivia, Chile (39 $47^{\circ} \mathrm{S}$ and $73^{\circ} 14^{\prime} \mathrm{W}$ ). The study began in spring 2008 and was carried through to spring 2011, and the objective was to evaluate the cumulative effect of DHA restriction on pasture-based dairy production systems.

The dietary treatments used in this study, including the two herbage allowances (low and high), are shown in Table 1. Productive results from this study can be obtained from Balocchi et al. (2013). During the third spring of this study, from October $16^{\text {th }}$ to December $21^{\text {st }}, 2010$, a 63-day period, the present experiment was conducted.

The climate of the location has been classified as temperate with Mediterranean influences. The soil is a moderately deep Andisol (Duric Hapludand) Valdivia Series soil, with plane topography (3\%) and without drainage problems.

The study utilized 27.9 ha of 12-year-old ryegrassdominated pasture (Lolium perenne L.), which had been subjected to rotational grazing management. Twenty-two paddocks, classified in autumn 2008 as high $(n=13)$ or low $(n=9)$ DHA paddocks, each approximately 1.2 ha, were used.

Fertilizer was applied twice before the experiment started. Fertilizer levels per hectare were $52 \mathrm{~kg} \mathrm{P}, 50 \mathrm{~kg} \mathrm{~K}$ and $46 \mathrm{~kg} \mathrm{~N}$ in autumn, and 46 $\mathrm{kg} \mathrm{N}$ were applied in spring, based on a potential production level of $12 \mathrm{t} \mathrm{DM} \mathrm{ha}^{-1}$ year $^{-1}$.

\section{Animals}

Sixty-four Holstein-Friesian dairy cows, 32 in early lactation (milk yield, $29 \pm 5.7 \mathrm{~kg} \mathrm{cow}^{-1}$ day $^{-1}$; days in milk, $59 \pm 33$ days; body weight (BW), $530 \pm 63$ $\mathrm{kg}$; body condition score (BCS), $2.7 \pm 0.4$ points on a scale of 1-5) and 32 in late lactation (milk yield, 
Table 1. Daily herbage allowance, concentrate and grass silage supplementation during the study $\left(\mathrm{kg} \mathrm{DM} \mathrm{cow}{ }^{-1}\right.$ day $\left.^{-1}\right)$

\begin{tabular}{|c|c|c|c|c|}
\hline Season of the year & Spring & Summer & Autumn & Winter \\
\hline \multicolumn{5}{|l|}{ Year 1 (2008-2009) } \\
\hline Grass silage & 0 & 6 & 4 & 7 \\
\hline Concentrate & 3 & 3 & 3 & 3 \\
\hline \multicolumn{5}{|c|}{ Daily herbage allowance } \\
\hline High Allowance & 38 & 26 & 30 & 25 \\
\hline Low allowance & 26 & 14 & 20 & 16 \\
\hline \multicolumn{5}{|l|}{ Year 2 (2009-2010) } \\
\hline Grass silage & 0 & 0 & 6 & 6 \\
\hline Concentrate & 3 & 3 & 3 & 3 \\
\hline \multicolumn{5}{|c|}{ Daily herbage allowance } \\
\hline High Allowance & 30 & 30 & 25 & 22 \\
\hline Low allowance & 20 & 20 & 17 & 15 \\
\hline \multicolumn{5}{|l|}{ Year 3 (2010-2011) } \\
\hline Grass silage & 0 & 0 & 6 & 6 \\
\hline Concentrate & 3 & 3 & 3 & 3 \\
\hline \multicolumn{5}{|c|}{ Daily herbage allowance } \\
\hline High Allowance & 30 & 30 & 25 & 25 \\
\hline Low allowance & 20 & 20 & 20 & 17 \\
\hline
\end{tabular}

DM, Dry matter; Daily herbage allowance measured at ground level

$23 \pm 4 \mathrm{~kg} \mathrm{cow}^{-1}$ day $^{-1}$; days in milk, $206 \pm 10$ days; BW, $544 \pm 85 \mathrm{~kg}$ and BCS, $3.0 \pm 0.4$ points), were randomly selected from the University dairy herd (all values expressed as the mean $\pm \mathrm{SD}$ ). Cows were assigned to one of two DHA treatments (low: 20 $\mathrm{kg} \mathrm{DM} \mathrm{cow}{ }^{-1}$ day $^{-1}$ and high: $30 \mathrm{~kg} \mathrm{DM} \mathrm{cow}^{-1}$ day $^{-1}$, measured to ground level), according to a complete randomized experimental design.

The levels of DHA used in this study were determined by achieving predetermined levels of post-grazing herbage mass, and according to previous experimental studies performed in this project, the DHA levels allowed the forage plants time to rest and regrow.

\section{Diets and grazing management}

Cows were milked twice daily, and supplements were individually supplied in two equal por- tions in the morning (06 AM) and evening (15 PM), on the milking parlor feeding system. The chemical composition of the concentrate, based on cereal grain offered, was 13.56 MJ per kg DM of metabolizable energy (ME), 10\% DM of crude protein $(\mathrm{CP})$ and $6 \% \mathrm{DM}$ of neutral detergent fiber (NDF). Cows had free access to water at all times.

Each group of cows was managed in a rotational grazing system in half-day strips, so that there was access to new pasture after each milking. Herds grazed at different paddocks classified as high or low DHA according to the corresponding treatment. The paddocks, classified in 2008 as low and high DHA (13 high and 9 low), were grazed to a similar pre-grazing herbage mass, between 2200 and $2800 \mathrm{~kg} \mathrm{DM} \mathrm{ha}^{-1}$, during the experimental period. Daily herbage allowance was provided by adjusting the daily strip area using front and back electric fences. 


\section{Pasture measurements}

Pre-grazing herbage mass was estimated in each paddock using a rising plate meter (Jenquip, New Zealand) to limit the offered area. Measurements were made by walking along the paddocks in a "W" pattern. The procedure was repeated after grazing to determine post-grazing herbage mass (i.e., the amount of pasture remaining following grazing).

The rising plate meter was calibrated periodically by double sampling, which meant taking ten samples pre- and post-grazing $\left(0.1 \mathrm{~m}^{2}\right)$. The sample cutting was done at ground level with an electric mower. The samples were dried at $60{ }^{\circ} \mathrm{C}$ for 48 hours and then weighed, and the results were transformed to $\mathrm{kg} \mathrm{DM} \mathrm{ha}{ }^{-1}$. The data pairs of the compressed height $(1 / 2 \mathrm{~cm})$ and the herbage mass $\left(\mathrm{kg} \mathrm{DM} \mathrm{ha}^{-1}\right)$ were graphed, and then the respective linear equations $(y=a+b x)$ were generated, where $y$ is the herbage mass, a is the intercept, $b$ is the increase in herbage mass for each $1 / 2 \mathrm{~cm}$ of compressed height, and $\mathrm{x}$ is the compressed height of the pasture expressed in $1 / 2 \mathrm{~cm}$.

The difference between pre-grazing and postgrazing herbage mass for each grazing strip was assumed to be consumed by the 32 cows in each group and to represent the pasture intake per hectare $\left[\right.$ Pasture $\left.\mathrm{DMI}_{(\mathrm{ha})}\right]$. Apparent daily pasture intake per cow was estimated from the pasture intake per ha in each grazing time period (morning and afternoon grazing events), according to the following equation:

$\mathrm{DMI}_{(\mathrm{kg} \text { DM cow-l day-1) }}=\left[\left(\right.\right.$ Daily Pasture DMI ${ }_{(\text {ha) }} \times$ daily offered area) / $10000 \mathrm{~m}^{2}$ ] / 32 cows

The offered area and efficiency of harvesting were recorded for each grazing event. The efficiency of harvesting was defined as the amount of pasture that disappeared (apparent pasture intake) as a proportion of pasture provided.

Herbage mass at sward height above and below $4 \mathrm{~cm}$ was measured each week on the low and high DHA paddocks that were to be grazed the next day. Herbage mass above $4 \mathrm{~cm}$ represents the proportion of the total herbage mass of the pasture available for animal consumption. It was calculated by cutting three strips $(0.6 \times 6 \mathrm{~m})$ for each paddock with a grass cutting machine (Husqvarna 5521P, Sweden). Herbage mass below $4 \mathrm{~cm}$ was determined after harvesting the remaining forage with a ring of $0.250 \mathrm{~m}^{2}$ randomly placed 3 times on each cut strip. The fresh weights of herbage samples from each strip were weighed and then dried for $48 \mathrm{~h}$ at $60{ }^{\circ} \mathrm{C}$ in a forced-air oven for DM determination. The results were extrapolated to $\mathrm{kg} \mathrm{DM} \mathrm{ha-1}$ above and below $4 \mathrm{~cm}$.

Once a week, herbage mass proportions above and below $4 \mathrm{~cm}$ and the chemical composition of the pasture provided $(>4 \mathrm{~cm})$ were estimated from the high and low DHA paddocks that were to be grazed the following day. Three strips of $3.6 \mathrm{~m}^{2}$ were cut to a height of $4 \mathrm{~cm}$, which was the height at which cows grazed, with a grasscutting machine (Husqvarna 5521P, Sweden). The herbage harvested from each strip was weighed, and two samples of approximately $100 \mathrm{~g}$ each were taken at random and dried in a forced-air oven at $60^{\circ} \mathrm{C}$ to obtain the dry matter weight and to assess the chemical composition of the herbage provided. Herbage was analyzed for crude protein (CP; Bateman, 1970), neutral detergent fiber (NDF; Van Soest et al., 1991), acid detergent fiber (ADF; AOAC, 1996), digestible organic matter on a dry matter basis (DOMD; Tilley and Terry, 1963) and water-soluble carbohydrates (WSC; Thomas, 1977). Analyses were performed at the Animal Nutrition Laboratory, University Austral of Chile.

Botanical composition, structure and density of the pasture species were evaluated on the fifth week of the experimental period from six randomly selected high and low DHA paddocks. Botanical composition was determined by cutting 20 herbage samples at ground level using a 0.04 $\mathrm{m}^{2}$ quadrant randomly placed in each paddock. Species proportions were calculated by hand- 
separation, and their corresponding contributions to total dry matter were estimated after oven drying them for $48 \mathrm{~h}$ at $60^{\circ} \mathrm{C}$.

Sward structure, evaluated as the vertical distribution of herbage mass in the pasture profile, was estimated in three randomly chosen areas per paddock. A stratified clip method was used for the estimation of the herbage mass and its vertical distribution. An herbage gripping structure held a sample of herbage from a $20 \times 5 \mathrm{~cm}$ area while it was harvested and cut into 6 layers, each at 4 $\mathrm{cm}$ depth $(0-4,4-8,8-16,16-20$ and $>20 \mathrm{~cm})$ from the top to the bottom of the canopy. Independent herbage samples were dried and weighed in the laboratory, and the DM herbage mass within each layer was calculated.

The density of the pasture species was measured from eight samples per paddock and was based on the core technique of Mitchell and Glenday (1958) and the ranking method of McIntyre (1951). Within each 78-mm-diameter core, the number of grass tillers, the white clover growing points and the weeds were counted to estimate species density $\left(n\right.$ per $\left.\mathrm{m}^{2}\right)$.

Changes in the pasture during the grazing session

During the three 5-hour grazing events (from 0800 and 1300), changes in the grazed pasture were determined by measuring sward surface heights using a first-contact technique with a sward stick (Barthram, 1986) and by measuring herbage mass with a rising plate meter (Mitchell, 1982). Measurements were made in each paddock at 30-min intervals, enabling the grass disappearance of each grazing strip to be calculated. The reduction of sward height and herbage mass was defined as the difference between initial and final values for each measurement period and was expressed as a percentage of the initial value. At the same time, grazing activity and bite rates were monitored. Grazing activity was estimated by observing the number of cows grazing at 10 -min intervals.
Cows were considered to be eating when bowing their heads down and consuming herbage (Gibb, 1998). Bite rates were determined by observing the number of bites taken over a one-min period using a hand-held counter at the beginning and near the end of the grazing event. Morphological components $(>4 \mathrm{~cm})$ were measured at the beginning (T1; $0800 \mathrm{~h})$, middle (T2; $1030 \mathrm{~h}$ ) and end (T3; $1300 \mathrm{~h}$ ) of the grazing event. Over each time period, 9 herbage samples were cut at $4 \mathrm{~cm}$ above ground level using shearing scissors and a quadrant of $0.04 \mathrm{~m}^{2}$. Herbage samples were separated into lamina, sheath, stem and dead material and were oven-dried at $60{ }^{\circ} \mathrm{C}$ for $48 \mathrm{~h}$. Thereafter, the results were converted to $\mathrm{kg} \mathrm{DM} \mathrm{ha}{ }^{-1}$.

\section{Animal measurements}

Three times a week, individual milk production was recorded using Waikato milk meters (Waikato ${ }^{\circledR}$, New Zealand). Milk composition (protein and fat) was determined from samples collected at morning and afternoon milkings three times during the experimental period (weeks 3, 7 and 11). Milk samples were analyzed by infrared spectrophotometry (Milko-scan, System 4300 Foss Electric Denmark). Cows were weighed, and their body condition scores were measured once a week after the morning milking using a five-point scale ( $1=$ emaciated, $5=$ extremely fat; Ferguson et al., 1994).

\section{Statistical analysis}

The pasture management variables, vertical distribution of herbage mass, pasture structure, botanical composition, the changes in morphological components during the grazing event and bite rates were evaluated with a T-test. A general linear model was used to evaluate the herbage mass above and below $4 \mathrm{~cm}$ and the chemical composition of the pasture offered. The dynamics of herbage depletion during the grazing session and the grazing activity were evaluated with a general 
linear model considering minutes as a covariance factor. Animal performance data (milk production and composition) and animal condition data (BW and BCS) were analyzed using covariance analysis by PROC Mixed (SAS Institute, 1999). For all of the pasture-related measurements, the experimental unit was the paddock, and for the animal-related measurements, each cow was considered as an experimental unit.

\section{Results}

\section{Weather}

Daily temperatures during the experimental period were similar to previous years with an average of $13.1{ }^{\circ} \mathrm{C}$ (a minimum of $8.1{ }^{\circ} \mathrm{C}$ and a maximum of $18.7^{\circ} \mathrm{C}$ ). Spring 2010 was $23 \%$ drier than the historical average (40 years), especially in September (Table 2).

\section{Grazing management}

Pasture management variables are presented in Table 3. Pre-grazing herbage mass was similar between DHA levels ( $\mathrm{P}>.05)$. However, daily herbage allowance significantly affected postgrazing herbage mass $(\mathrm{P}<.01)$. Cows offered low DHA had $127 \mathrm{~kg}$ lower post-grazing herbage mass than cows with high DHA.

Pre-grazing compressed sward height did not differ between treatments and averaged $9.3 \mathrm{~cm}$. In contrast, post-grazing compressed sward height was $0.7 \mathrm{~cm}$ lower in the low treatment compared to the high DHA treatment $(\mathrm{P}<.01)$.

Daily herbage allowance did not affect herbage intake per hectare, but the apparent herbage intake of individual cows was $2.9 \mathrm{~kg} \mathrm{~d}^{-1}$ lower in the low treatment compared to the high DHA treatment $(\mathrm{P}<.001)$.

High DHA increased the offered grazing area $\left(+45 \mathrm{~m}^{2}\right.$ cow $^{-1}$ day $\left.^{-1}\right)$ but decreased the harvesting efficiency from 47 to $41 \%(\mathrm{P}<.01)$.

\section{Pasture characteristics}

The proportion of herbage mass above and below $4 \mathrm{~cm}$ and the vertical distribution of the herbage mass of the pasture were not significantly affected by daily herbage allowance (Table 4).

Distribution of herbage mass in the vertical plane showed higher amounts of herbage mass closer to ground level, with an average of $56 \%$ between both treatments below $4 \mathrm{~cm}$.

Botanical compositions are presented in Table 5. The most common species in the pasture was Lolium perenne, followed by Bromus valdivianus and Holcus lanatus. No effect was observed on botanical composition, pasture stocking density and plant dry weight due to restricted daily herbage allowance $(\mathrm{P}>.05)$. Daily herbage allowance did not modify the number of grass tillers.

Table 2. Average daily temperatures and rainfall during the experiment and the historical averages

\begin{tabular}{lcccc}
\hline \multirow{2}{*}{ Month } & \multicolumn{2}{c}{ Temperatures $\left({ }^{\circ} \mathrm{C}\right)$} & \multicolumn{2}{c}{ Rainfall $(\mathrm{mm})$} \\
\cline { 2 - 5 } & Mean period & Historical & Mean period & Historical \\
\hline September & 9.7 & 9.7 & 82.6 & 183.0 \\
October & 12.5 & 11.6 & 127.4 & 151.6 \\
November & 13.4 & 13.7 & 110.7 & 106.6 \\
December & 14.5 & 15.8 & 89.6 & 90.5 \\
\hline
\end{tabular}

Information was collected from a meteorological station (Geoscience Institute. University Austral of Chile, Valdivia, Chile). 
Table 3. Effect of daily herbage allowance on pre- and post-grazing herbage mass, pre- and post-grazing sward height, apparent pasture intake, offered area and efficiency of harvesting, estimated daily by using a rising plate meter

\begin{tabular}{|c|c|c|c|c|}
\hline & \multicolumn{2}{|c|}{ Daily Herbage Allowance } & \multirow{3}{*}{ s.e.m. } & \multirow{3}{*}{ Significance $^{\dagger}$} \\
\hline & 20 & 30 & & \\
\hline & \multicolumn{2}{|c|}{$\left(\mathrm{kg} \mathrm{DM} \mathrm{cow}{ }^{-1}\right.$ day $\left.^{-1}\right)$} & & \\
\hline \multicolumn{5}{|l|}{ Herbage mass, $\mathrm{kg} \mathrm{DM} \mathrm{ha}^{-1}$} \\
\hline Pre-grazing & 2260 & 2253 & 45.57 & n.s. \\
\hline Post-grazing & 1203 & 1330 & 24.60 & $* *$ \\
\hline \multicolumn{5}{|l|}{ Compressed sward height, $\mathrm{cm}$} \\
\hline Pre-grazing & 9.3 & 9.3 & 0.44 & n.s. \\
\hline Post-grazing & 4.0 & 4.7 & 0.12 & $* *$ \\
\hline \multicolumn{5}{|l|}{ Pasture intake } \\
\hline Per hectare, $\mathrm{kg}^{\mathrm{DM}} \mathrm{ha}^{-1}$ & 1058 & 923 & 39.65 & n.s. \\
\hline Per cow, kg DM cow ${ }^{-1} \mathrm{~d}^{-1}$ & 9.3 & 12.2 & 0.39 & $* * *$ \\
\hline Offered area, $\mathrm{m}^{2}$ cow $^{-1} \mathrm{~d}^{-1}$ & 89 & 134 & 5.39 & n.s. \\
\hline Efficiency of harvesting, \% & 47 & 41 & 1.10 & $* *$ \\
\hline
\end{tabular}

Table 4. Effect of daily herbage allowance on herbage mass above and below $4 \mathrm{~cm}$ and on the vertical distribution of herbage mass from the top of the canopy to ground level

\begin{tabular}{|c|c|c|c|c|}
\hline & \multicolumn{2}{|c|}{$\begin{array}{c}\text { Daily Herbage } \\
\text { Allowance }\end{array}$} & \multirow{3}{*}{ s.e.m. } & \multirow{3}{*}{ Significance ${ }^{\dagger}$} \\
\hline & 20 & 30 & & \\
\hline & \multicolumn{2}{|c|}{$\begin{array}{c}\left(\begin{array}{c}\text { kg DM cow } \\
\text { day }\end{array}\right. \\
\left.\text { day }^{-1}\right)\end{array}$} & & \\
\hline \multicolumn{5}{|c|}{$\begin{array}{l}\text { Herbage mass, kg } \\
\mathrm{DM} \mathrm{ha}^{-1}\end{array}$} \\
\hline Above $4 \mathrm{~cm}$ & 1493 & 1378 & 20.03 & n.s. \\
\hline Below $4 \mathrm{~cm}$ & 1770 & 1800 & 15.92 & n.s. \\
\hline \multicolumn{5}{|c|}{ Herbage mass ${ }^{\ddagger}$} \\
\hline Above $4 \mathrm{~cm}$ & 44.8 & 42.7 & 1.63 & n.s. \\
\hline Below $4 \mathrm{~cm}$ & 55.2 & 57.3 & 1.63 & n.s. \\
\hline \multicolumn{5}{|c|}{$\begin{array}{l}\text { Vertical } \\
\text { distribution of } \\
\text { herbage mass }\end{array}$} \\
\hline$>20 \mathrm{~cm}$ & 6.0 & 3.7 & 1.38 & n.s. \\
\hline $16-20 \mathrm{~cm}$ & 4.7 & 4.2 & 0.42 & n.s. \\
\hline $12-16 \mathrm{~cm}$ & 7.7 & 6.0 & 0.57 & n.s. \\
\hline $8-12 \mathrm{~cm}$ & 11.0 & 10.1 & 0.64 & n.s. \\
\hline $4-8 \mathrm{~cm}$ & 15.3 & 17.7 & 0.95 & n.s. \\
\hline$<4 \mathrm{~cm}$ & 55.3 & 58.3 & 2.21 & n.s. \\
\hline
\end{tabular}

†.s., not significant $(\mathrm{P}>0.05)$.

tValues are expressed as a percentage of dry matter.
The chemical composition of the pastures offered $(>4 \mathrm{~cm})$ is shown in Table 6 . The pastures did not differ between DHA treatments and contained on average $21 \% \mathrm{CP}, 12 \%$ metabolizable energy and $39 \%$ NDF.

The morphological composition of the pastures offered $(>4 \mathrm{~cm})$ was not different between treatments at the beginning, middle or end of the grazing event (Table 7).

Effect of DHA on the changes in the pasture throughout the grazing event

Sward height and herbage mass throughout the grazing events are shown in Figure 1. Reduction of sward height and herbage mass was considered to be the difference between the initial and final values for both periods of measurement. Sward height and herbage mass changed markedly as the day progressed with an exponential depletion and were not affected by DHA. However, both tended to be higher at low versus high DHA treatments. The average sward height reduction was $75 \%$ and $68 \%$ for low and high DHA, respectively. Herbage mass reduction was $56 \%$ for low DHA and $54 \%$ for high 
Table 5. Effect of daily herbage allowance on the botanical composition and pasture density

\begin{tabular}{|c|c|c|c|c|}
\hline & \multicolumn{2}{|c|}{$\begin{array}{l}\text { Daily Herbage } \\
\text { Allowance }\end{array}$} & \multirow{3}{*}{ s.e.m. } & \multirow{3}{*}{ Significance } \\
\hline & 20 & 30 & & \\
\hline & \multicolumn{2}{|c|}{$\begin{array}{c}\left(\begin{array}{l}\text { kg DM cow } \\
\text { Day }\end{array}\right. \\
\left.\text { day }^{-1}\right)\end{array}$} & & \\
\hline \multicolumn{5}{|l|}{$\begin{array}{l}\text { Botanical } \\
\text { composition, \% } \\
\text { of DM }\end{array}$} \\
\hline Lolium perenne & 43.3 & 39.8 & 5.8 & n.s. \\
\hline $\begin{array}{l}\text { Bromus } \\
\text { valdivianus }\end{array}$ & 14.9 & 15.2 & 1.1 & n.s. \\
\hline Holcus lanatus & 15.2 & 15.4 & 2.2 & n.s. \\
\hline $\begin{array}{l}\text { Agrostis } \\
\text { capillaris }\end{array}$ & 4.9 & 8.1 & 2.3 & n.s. \\
\hline Other grasses & 5.0 & 4.5 & 0.9 & n.s. \\
\hline $\begin{array}{l}\text { Trifolium } \\
\text { repens }\end{array}$ & 5.1 & 5.1 & 1.2 & n.s. \\
\hline Broad leaf & 11.6 & 11.9 & 2.5 & n.s. \\
\hline \multicolumn{5}{|c|}{ Pasture density, tillers or number of plants per $\mathrm{m}^{2}$} \\
\hline Grass tillers & 7595 & 6900 & 881 & n.s. \\
\hline $\begin{array}{l}\text { Trifolium } \\
\text { repens }\end{array}$ & 345 & 358 & 57 & n.s. \\
\hline Broad leaf & 324 & 695 & 127 & n.s. \\
\hline \multicolumn{5}{|l|}{$\begin{array}{l}\text { Weight, mg per } \\
\text { tiller or plant }\end{array}$} \\
\hline Grass tillers & 14.1 & 9.8 & 3.3 & n.s. \\
\hline $\begin{array}{l}\text { Trifolium } \\
\text { repens }\end{array}$ & 14.4 & 17.9 & 2.3 & n.s. \\
\hline Broad leaf & 55.6 & 16.5 & 10.6 & $*$ \\
\hline
\end{tabular}

'n.s., not significant $(\mathrm{P}>0.05)$; *, significant $(\mathrm{P}<0.05)$.

DHA. The effects of daily herbage allowance on sward morphological changes as grazing progressed are shown in Table 7. The pasture components were similar between treatments for all variables. The proportion of lamina decreased as grazing time progressed $(\mathrm{P}<.001)$, and the proportion of sheath, stem and dead material increased as the cows grazed progressively down through the pasture.

\section{Effect ofDHA on milkproduction, milk composition, body weight and body condition score}

The daily herbage allowance effects on animal performance and milk composition are shown in Table 8. No effect was observed on the individual
Table 6. Effect of daily herbage allowance on the chemical composition of pasture offered $(>4 \mathrm{~cm})$

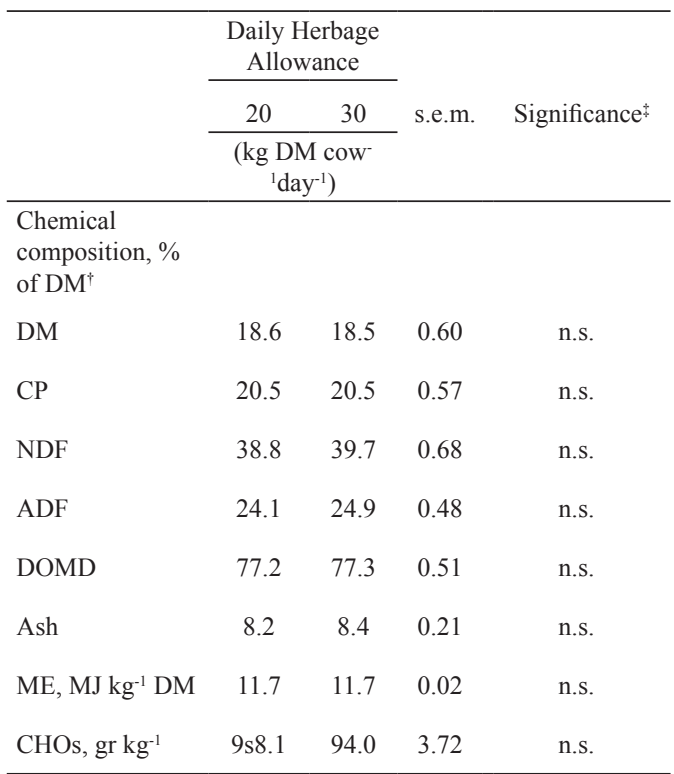

'DM, Dry matter; CP, Crude protein; NDF, Neutral detergent fiber; ADF, Acid detergent fiber; DOMD, digestible organic matter on a dry matter basis; ME, Metabolizable energy and WSC, Water-soluble carbohydrates.

${ }^{\ddagger}$ n.s., not significant $(\mathrm{P}>0.05)$.

Table 7. Effect of daily herbage allowance on the variation in the morphological components of the pasture above $4 \mathrm{~cm}$ throughout a 5-hour grazing event

\begin{tabular}{|c|c|c|c|c|}
\hline \multirow{3}{*}{$\begin{array}{l}\text { Morphological } \\
\text { component }\end{array}$} & \multicolumn{2}{|c|}{$\begin{array}{c}\text { Daily Herbage } \\
\text { Allowance }\end{array}$} & \multirow{3}{*}{ s.e.m. } & \multirow{3}{*}{ Significance $^{\dagger}$} \\
\hline & 20 & 30 & & \\
\hline & \multicolumn{2}{|c|}{$\begin{array}{c}\left(\begin{array}{l}\text { kg DM cow } \\
\text { DM } \\
\left.\text { day }^{-1}\right)\end{array}\right. \\
\end{array}$} & & \\
\hline \multicolumn{5}{|l|}{ Lamina } \\
\hline Initial, $\%$ & 69.1 & 69.5 & 3.37 & n.s. \\
\hline Middle, $\%$ & 51.9 & 51.9 & 3.09 & n.s. \\
\hline Final, \% & 46.7 & 52.5 & 3.29 & n.s. \\
\hline \multicolumn{5}{|l|}{ Sheath } \\
\hline Initial, $\%$ & 11.8 & 11.0 & 0.96 & n.s. \\
\hline Middle, $\%$ & 16.5 & 16.0 & 0.96 & n.s. \\
\hline Final, \% & 18.2 & 16.6 & 1.02 & n.s. \\
\hline \multicolumn{5}{|l|}{ Stem } \\
\hline Initial, $\%$ & 15.2 & 16.0 & 2.21 & n.s. \\
\hline Middle, \% & 20.4 & 24.8 & 2.45 & n.s. \\
\hline Final, \% & 21.0 & 18.7 & 1.02 & n.s. \\
\hline \multicolumn{5}{|l|}{ Dead material } \\
\hline Initial, $\%$ & 3.9 & 3.5 & 0.58 & n.s. \\
\hline Middle, \% & 11.2 & 7.3 & 1.07 & n.s. \\
\hline Final, \% & 14.1 & 12.2 & 1.40 & n.s. \\
\hline
\end{tabular}

†n.s., not significant $(\mathrm{P}>0.05)$. 

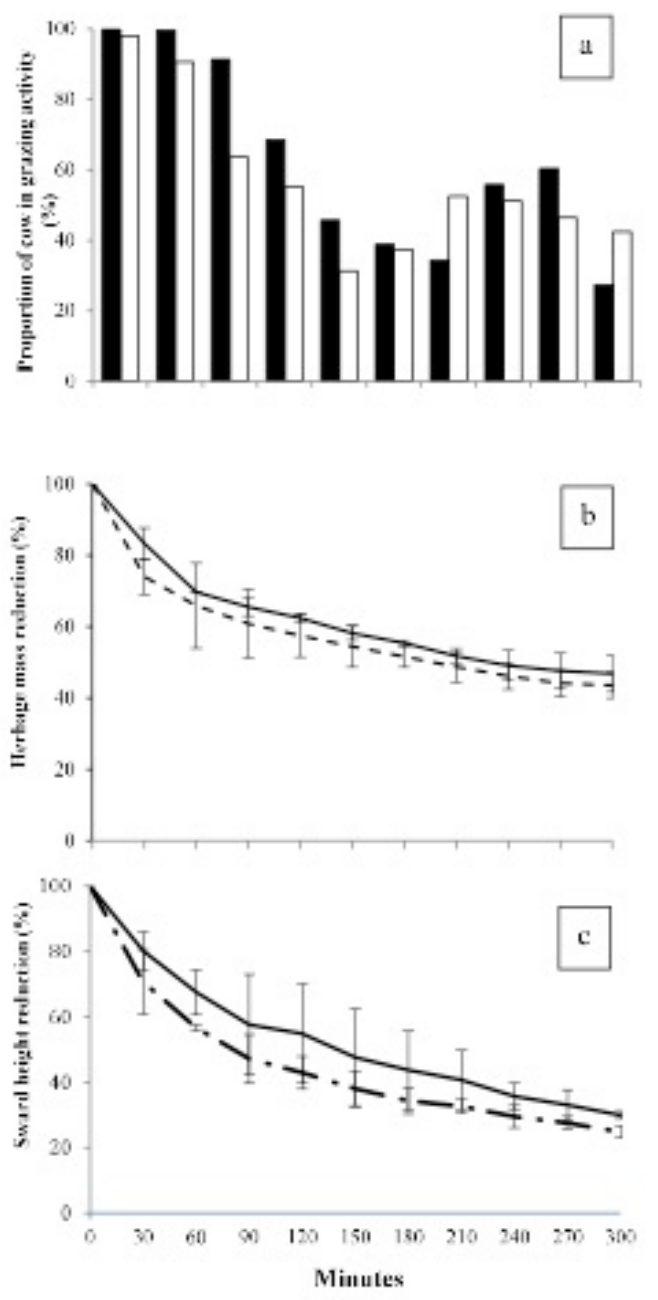

Figure 1. a, Proportion of cows in grazing activity; b, proportion of herbage mass reduction; c, proportion of sward height depletion, by daily herbage allowance treatment. Data are the means from two grazing event measurements. Black and white bars represent high and low herbage allowance treatments, respectively. Curves were fitted for the high (solid line) and low (short-dashed line) herbage allowance treatments. milk production of dairy cows in response to an increase in DHA from 20 to $30 \mathrm{~kg} \mathrm{DM}_{\text {cow }}{ }^{-1}$ day $^{-1}$ (both average allowances at $24.5 \mathrm{~kg} \mathrm{day}^{-1}$ ). Neither milk composition, body weight nor body condition score were affected by DHA $(\mathrm{P}>05)$. Daily herbage allowance did not affect the biting rate at either the beginning or at the end of the grazing time (average high DHA: $57 \pm 2.8$ bites $\min ^{-1}$, low DHA: $58 \pm 2.2$ bites $\min ^{-1}$ ).

\section{Discussion \\ Grazing management}

As was expected, pre-grazing herbage masses and compressed sward heights were unaffected by DHA treatments, averaging $2257 \mathrm{~kg} \mathrm{DM} \mathrm{ha}^{-1}$ of pre-grazing herbage mass and an average compressed sward height of $9.3 \mathrm{~cm}$. These results are consistent with those reported by Delaby et al. (2001) and Kennedy et al. (2008) and are within the range of recommended pre-grazing herbage mass in southern Chile during spring (Teuber $e t$ al., 2007). The results showed that all cows graze in similar pasture conditions.

Dairy cows grazing at low DHA resulted in a greater stocking rate $\left(+0.7\right.$ cow ha $\left.{ }^{-1}\right)$ and grazing intensity, as evidenced by lower post-grazing herbage mass (-127 $\left.\mathrm{kg} \mathrm{DM} \mathrm{ha}^{-1}\right)$ and post-grazing sward height $(-0.7 \mathrm{~cm})$ compared with high DHA treatments. The results are in line with previous experiments by Dalley et al. (1999) and McEvoy

Table 8. Effect of daily herbage allowance on milk production, milk composition, body weight and condition score of dairy cows

\begin{tabular}{|c|c|c|c|c|}
\hline & \multicolumn{2}{|c|}{ Daily Herbage Allowance } & \multirow{3}{*}{ s.e.m. } & \multirow{3}{*}{ Significance } \\
\hline & 20 & 30 & & \\
\hline & \multicolumn{2}{|c|}{$\left(\mathrm{kg} \mathrm{DM} \mathrm{cow}^{-1}\right.$ day $\left.^{-1}\right)$} & & \\
\hline Milk production, $\mathrm{kg} \mathrm{d}^{-1}$ & 24.8 & 24.2 & 0.35 & n.s. \\
\hline Milk fat, $\%$ & 3.6 & 3.7 & 0.06 & n.s. \\
\hline Milk protein, $\%$ & 3.4 & 3.4 & 0.04 & n.s. \\
\hline Body weight, kg & 543.3 & 567.7 & 8.08 & n.s. \\
\hline Body condition score, scale 1-5 & 3.0 & 3.0 & 0.06 & n.s. \\
\hline
\end{tabular}

†n.s., not significant $(\mathrm{P}>0.05)$. 
et al. (2009). As DHA offered to the animals was reduced, daily grazing pressure increased from 27 to 31 cows $\mathrm{t}^{-1}$ of pasture DM (considering a daily herbage intake of $15 \mathrm{~kg} \mathrm{DM} \mathrm{cow}^{-1}$ ), and the grazing efficiency increased from 41 to $47 \%$, due to a smaller area offered $\left(-45 \mathrm{~m}^{2}\right.$ cow $^{-1}$ day $\left.^{-1}\right)$ compared with the high DHA treatment.

Despite the absence of significant differences in pasture intake per hectare between treatments, there were differences in the pasture intake per cow, which increased by $0.29 \mathrm{~kg}$ per $\mathrm{kg}$ of increase on DHA, which is probably related to the greater pasture availability per cow (McCarthy et al., 2011) and offered area. The average increase in pasture intake per kilogram of increase in DHA was higher than the $0.21 \mathrm{~kg}$ reported by PérezPrieto and Delagarde (2013) in which DHA was estimated at ground level (between 20 and $40 \mathrm{~kg}$ DM cow ${ }^{-1}$ day $^{-1}$ in different seasons and years) but was only slightly higher than the $0.23 \mathrm{~kg}$ reported by Peyraud et al. (1996) in which 19, 29 and 46 $\mathrm{kg} \mathrm{DM} \mathrm{cow}^{-1}$ day $^{-1}$ were offered in spring.

The increased pasture DM intake per cow that was achieved when high DHA was offered $(+31 \%)$ was proportionally lower than the $50 \%$ increase on daily herbage allowance level compared to low DHA. Bargo et al. (2002) found that the pasture intake of unsupplemented dairy cows increased by $16 \%$ as DHA increased from 25 to $40 \mathrm{~kg}$ DM cow $^{-1}$ day $^{-1}$ (above ground level).

\section{Pasture characteristics}

The results indicate that although the low DHA treatment had lower levels of post-grazing herbage mass and sward height than the high DHA in spring, the cumulative effect of increased grazing pressure had no effect on the vertical distribution of herbage mass. This might be because the botanical composition of the pasture, pasture species density and individual plant weights were unaffected by DHA. Tiller density was in the range of 6300 to 10000 tillers per $\mathrm{m}^{2}$, which matches the density previously reported by Balocchi et al. (1989) for permanent pastures in Valdivia, Chile.

High DHA can reduce pasture quality because it increases post-grazing pasture height (Peyraud and Delaby, 2001). In the present study, the decreased stocking rate in the high DHA treatment had no effect on the proportion of lamina, stem and dead material, which might be causing the similarity in chemical compositions in the DHA treatment pastures. Pasture chemical composition values ( $>$ $4 \mathrm{~cm}$ ) are comparable to those typically observed for early spring growth in temperate pastures, with high levels of $\mathrm{CP}$ and $\mathrm{ME}$ and low levels of NDF (Bargo et al., 2003).

Effect of DHA on the changes in sward height, herbage mass and morphological composition throughout the grazing event

The defoliation pattern throughout the grazing event was not affected by the daily herbage allowance and was marked by a progressive reduction in pasture height and herbage mass, averaging a $75 \%$ reduction in sward height and $55 \%$ reduction in herbage mass.

A similar tendency toward sward height reduction was observed by Chilibroste et al. (2010), who

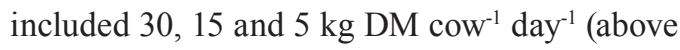
ground level) and cows that were rotated every 7 days to a new paddock. Because the levels of DHA in the study by Chilibroste et al. (2010) (5 and $15 \mathrm{~kg} \mathrm{DM} \mathrm{cow}^{-1}$ day $^{-1}$ ) were lower than the DHA treatments used in our study, the authors found a faster reduction in sward height $(70 \%$ reduction), which was represented by a $52 \%$ and $62 \%$ sward height reduction at high and low DHA, respectively; this was measured in the middle of the grazing period.

As the grazing event progressed, changes in the morphological components, herbage mass and sward height within the grazed horizon were not affected by the greater grazing pressure at 
low DHA. As the pasture was grazed down, the lamina proportion, herbage mass and sward height were reduced and the proportion of stem and dead material were increased, as shown by McGilloway et al. (1999). These components differ in digestibility, and variations in their relative proportions can affect sward quality. A lack of differences in the defoliation patterns of pasture grazed by dairy cows might be explained by the lack of differences in pasture structure between the DHA treatments. Moreover, daily herbage allowance did not affect the grazing activity pattern. However, grazing activity tended to decline in the herd that received a low DHA four hours after starting grazing, which suggests the ability of these animals to anticipate access to a new strip after milking, as described by Peyraud et al. (1996); this was attributed to a greater presence of stems, limiting the grazing depth (Barthram and Grant, 1984). Thus, in similar pasture conditions, the bite rate at the beginning and end of the grazing event was similar between DHA treatments.

Effect of DHA on milk production, milk composition, body weight and body condition score

The effects of DHA on the production of dairy cattle and grazing have been extensively studied (Combellas and Hodgson, 1979; Peyraud et al., 1996; Dalley et al., 1999; Bargo et al., 2003; McEvoy et al., 2008). In these studies, PérezPrieto and Delagarde (2013) showed that milk production increased from 0.05 to $0.19 \mathrm{~kg}$ per $\mathrm{kg}$ increase in DHA when daily herbage allowances from 20 to $40 \mathrm{~kg} \mathrm{DM} \mathrm{cow}^{-1}$ day $^{-1}$ were used (above ground level).

Decreasing DHA is considered to be similar to an increased stocking rate. As the stocking rate increases, the herbage availability and, consequently, milk production per cow are reduced (McCarthy et al., 2011). In our study, no significant effect was observed on individual milk production in response to a reduction in pasture intake associated with decreased DHA. This response might be related to the low energy balance that increases the milk production efficiency of dairy cows (Pérez-Prieto and Delagarde, 2013).

In the present study, the increased stocking rate as DHA decreased resulted in greater milk production per ha $(+27 \%)$, probably due to greater herbage utilization (Macdonald et al., 2008), and might improve the economic performance of grazing dairy systems in the long term.

There was no evidence of an adverse effect of daily herbage allowance restriction on the body weight and body condition score of lactating dairy cows. These findings are consistent with the results reported in a study with high producing dairy cows fed 25 and $40 \mathrm{~kg} \mathrm{DM} \mathrm{cow}^{-1}$ day $^{-1}$ (above ground level) (Bargo et al., 2002).

Decreasing DHA had no effect on the concentrations of milk fat and milk protein $(\mathrm{P}>.05)$, which is probably explained by the similar chemical composition (NDF content) in offered pastures (Stockdale, 1999) and the amount of energy supplements offered (Bargo et al., 2002). This result agrees with studies by Kennedy et al. (2008) and McEvoy et al. (2008).

The main conclusions are as follows. The current study shows that decreasing daily herbage allowance from 30 to $20 \mathrm{~kg} \mathrm{DM} \mathrm{cow}{ }^{-1}$ day $^{-1}$ during a 3 -year period has no negative effects on any pasture characteristics. Additionally, the results showed that in a high-quality spring pasture, there are no differences between daily herbage allowances on individual milk production, and there is increased herbage utilization and milk output per hectare $(+27 \%)$. Under such conditions, a daily herbage allowance of $20 \mathrm{~kg} \mathrm{DM} \mathrm{cow}^{-1}$ day $^{-1}$ appears to be a good management practice in order to improve the sustainability and profitability of pasture-based dairy systems. 


\section{Acknowledgement}

The financial support of the Comisión Nacional de Investigación Científica y Tecnológica (CONICYT, Chile) is acknowledged for providing the $\mathrm{PhD}$ scholarship for Mrs. Verónica Merino. This research was financed by the Dairy Consortium (Project M1P2) and FONDECYT (Project 1100513). The authors thank the person- nel of the Vista Alegre Experimental Research Station at the University Austral of Chile for grazing management and care of the animals, Felipe Zúñiga for his assistance with measurements throughout the study, and Andrea Baez for his valuable advice in the statistical analysis. Gratitude is also expressed to all personnel in the Laboratory of Animal Nutrition for their assistance with laboratory analyses.

\title{
Resumen
}

\begin{abstract}
V. Merino, O. Balocchi, y R. Pulido. 2018. Efecto acumulado de la restricción en la oferta diaria de pradera sobre las características de la pradera y sobre la producción de leche de vacas lecheras a pastoreo. Cien. Inv. Agr. 45(1): 21-34. El estudio evaluó el efecto acumulado de la restricción en la oferta diaria de pradera sobre las características de la pradera y sobre la sustentabilidad de los sistemas lecheros pastoriles. Se utilizaron 64 vacas lecheras que fueron asignadas aleatoriamente a dos tratamientos de pastoreo $\left(20\right.$ y $30 \mathrm{~kg} \mathrm{MS} \mathrm{vaca}^{-1}$ día $\left.^{-1}\right)$. En cada evento de pastoreo se registró la fitomasa de pre y post-pastoreo y la producción diaria de leche por vaca. Se evaluó la composición botánica y composición nutricional de la pradera. La baja oferta diaria de pradera aumentó la carga animal en 0,7 vacas ha $^{-1}$ y consecuentemente aumentó la eficiencia de de pastoreo de 41 a $47 \%$. La restricción en la oferta diaria de pradera, no modificó las características de la pradera ni la producción de leche por vaca, incrementando la producción de leche por hectárea en $27 \%$. Los resultados de este estudio sugieren que la restricción en la oferta diaria de pradera por vaca, aumenta la eficiencia de utilización de la pradera y la producción de leche por hectárea respecto de una alta oferta de pradera sin afectar negativamente las características y sustentabilidad de la pradera. Por lo tanto, la oferta diaria de pradera puede ser una herramienta útil de manejo del pastoreo para mejorar la rentabilidad y sustentabilidad de los sistemas lecheros basados en pastoreo.
\end{abstract}

Palabras clave: Manejo del pastoreo, producción de leche, sistemas lecheros, sustentabilidad, utilización de praderas.

\section{References}

Association of Official Analytical Chemists, AOAC. 1996. Official Methods of Analysis. 16th ed. AOAC, Gaithersburg, MD, USA.

Balocchi, O., R. Fuentes, and M. Jelves. 1989. Efecto de la aplicación de herbicida (2,4-D+dicamba) y del rastraje sobre la introducción de trébol blanco en praderas permanentes del sur de Chile. Agro Sur 17:41-49.

Balocchi, O., R. Pulido, and V. Merino. 2013. Oferta diaria de pradera: Efecto sobre el rendimiento y calidad de la pradera y sobre la producción de leche por vaca y por hectárea. Agro Sur 41:9-16.

Bargo, F, L.D. Muller, J.E. Delahoy, and T.W. Cassidy. 2002. Milk Response to Concentrate Supplementation of High Producing Dairy Cows Grazing at Two Pasture Allowances. J. Dairy Sci. 85:1777-1792.

Bargo, F., L.D. Muller, E.S. Kolver, and J.E. Delahoy. 2003. Invited Review: Production and Digestion of Supplemented Dairy Cows on Pasture. J. Dairy Sci. 86:1-42. 
Barthram, G.T., and S.A. Grant. 1984. Defoliation of ryegrass-dominated swards by sheep. Grass and Forage Sci. 39:211-219.

Barthram GT. 1986. Experimental techniques: the HFRO sward stick. In: Biennial Report Hill Farming Research Organization. Ed. M.M. Alcock, pp. 29-30. Hill Farming Research Organisation, Penicuik, Midlothian, UK.

Bateman, J.V. 1970. Nutrición Animal: Manual de Métodos Analíticos. Centro Regional de Ayuda Técnica, México D.F. p. 468.

Combellas, J., and J. Hodgson. 1979. Herbage intake and milk production by grazing dairy cows. 1 . The effects of variation in herbage mass and daily herbage allowance in a short-term trial. Grass and Forage Sci. 34:209-214.

Chilibroste, P, A. Meikle, D.A. Mattiauda, O. Bentancur, and P. Soca. 2010. The American Holstein dairy cow during early lactation: grazer or browser?. In: 'An overview of research on pastoral-based systems in the southern part of South America'. Machado, C.F., M. Wade, S. Carneiro da Silva, M. Agnusdei, P. de Faccio Carvalho, S. Morris, and W. Beskow eds. p 154-167.

Dalley, D.E., J.R. Roche, C. Grainger, and P.J. Moate. 1999. Dry matter intake, nutrient selection and milk production of dairy cows grazing rainfed perennial pastures at different herbage allowances in spring. Aus. J. Exp. Agric. 39:923-931.

Delaby, L., L. Peyraud, and R. Delagarde. 2001. Effect of the level of concentrate supplementation, herbage allowance and milk yield at turn-out on the performance of dairy cows in mid lactation at grazing. Animal Sci. 73:171-181.

Dillon, P., T. Hennessy, L. Shalloo, F. Thorne, and B. Horan. 2008. Future outlook for the Irish dairy industry: A study of international competitiveness, influence of international trade reform and requirement for change. Int. J. Dairy Tech. 61:16-29.

Ferguson, J.D., D.T. Galligan, and N. Thomsen. 1994. Principal descriptors of body condition score in Holstein cows. J. Dairy Sci. 77:2695-2703.

Gibb, M.J. 1998. Animal grazing/intake terminology and definitions. In: M.G. Keane, E.G. O'Riordan, eds. Pasture Ecology and Animal Intake. Teagasc, Grange Research Centre, Dunsany, Ireland. p. 21-37.

Kennedy, E., M. O'Donovan, L. Delaby, F.P. O'Mara. 2008. Effect of herbage allowance and concentrate supplementation on dry matter intake, milk production and energy balance of early lactating dairy cows. Livestock. Sci. 117:275-286.

Macdonald, K.A., J.W. Penno, J.A.S. Lancaster, and J.R. Roch. 2008. Effect of stocking rate on pasture production, milk production, and reproduction of dairy cows in pasture-based systems. J. Dairy Sci. 91:2151-2163.

McCarthy, B., L. Delaby, K.M. Pierce, F. Journot, and B. Horan. 2011. Meta-analysis of the impact of stocking rate on the productivity of pasture-based milk production systems. Animal 5:784-794.

McEvoy, M.E., E. Kennedy, J.P. Murphy, T.M. Boland, L. Delaby, M. O'Donovan. 2008. The effect of herbage allowance and concentrate supplementation on milk production performance and dry matter intake of spring-calving dairy cows in early lactation. J. Dairy Sci. 91:1259-1269.

McEvoy, M.E, M. O’Donovan, E. Kennedy, J.P. Murphy, L. Delaby, and T.M. Boland. 2009. Effect of pre-grazing herbage mass and pasture allowance on the lactation performance of Holstein-Friesian dairy cows. J. Dairy Sci. 92:414-422.

McGilloway, D.A., A. Cushnahan, A.S. Laidlaw, C.S. Mayne, D.J. Kilpatrick. 1999. The relationship between level of sward height reduction in a rotationally grazed sward and short-term intake rates of dairy cows. Grass and Forage Sci. 54:116-126.

McIntyre, M.A. 1951. A method for unbiased selective sampling, using ranked sets. Section of Mathematical Statistics, C.S.I.R.O., Canberra, A.C.T.

Mitchell, K.J., and A.C. Glenday. 1958. The tiller population of pastures. New Zeal. J. Agric. Res. 3:305-318.

Mitchell, P. 1982. Value of rising plate meter for estimation herbage mass of grazed perennial ryegrass-white clover dairy pastures. Proceedings of the New Zealand Grassland Association 49:117-122. 
Pérez-Prieto, L.A., and R. Delagarde. 2013. Metaanalysis of the effect of pasture allowance on pasture intake, milk production, and grazing behavior of dairy cows grazing temperate grasslands. J. Dairy Sci. 96:6671-6689.

Peyraud, J.L., E.A. Comeron, M.H. Wade, and G. Lemaire. 1996. The effect of daily herbage allowance, herbage mass and animal factors upon herbage intake by grazing dairy cows. Ann. Zootech. 45:201-217.

Peyraud, J.L., and L. Delaby. 2001. Ideal concentrate feeds for grazing dairy cows responses to supplementation in interaction with grazing management and grass quality, pp 203. In: Recent Advances in Animal Nutrition. Garnsworthy, P.C., and Wiseman J., editors. Nottingham University Press, UK.

Roca-Fernandez, A.I., A. Gonzalez-Rodriguez, and O.P. Vazquez-Yanez. 2012. Effect of pasture allowance and cows lactation stage on perennial ryegrass sward quality, pasture dry matter intake and milk performance of Holstein-Friesian cows. Spanish J. Agric. Res. 10:393-408.

Stakelum, G., J. Maher, and R. Rath. 2007. Effects of daily herbage allowance and stage of lactation on the intake and performance of dairy cows in early summer. Ir. J. Agric. Food Res. 46:47-61.

Stockdale, C.R. 1999. The nutritive characteristics of herbage consumed by grazing dairy cows affect milk yield responses obtained from concentrate supplementation. Aus. J. Exp. Agric. 39:379-387.

Teuber, N., O. Balocchi, and J. Parga. 2007. Grazing management $=$ Manejo del pastoreo.In: Fundación para la Innovación Agraria, Instituto de Investigaciones Agropecuarias, Chile. p. 129.

Thomas, T.A. 1977. An automated procedure for the determination of soluble carbohydrates in herbage. J. Sci. Food Agric. 28:639-642.

Tilley, J., and R. Terry. 1963. A two stages technique for the in vitro digestion of forage crops. J. Brit. Grassland Soc. 18:104-111.

Tozer, P.R., F. Bargo, and L.D. Muller. 2004. The Effect of Pasture Allowance and Supplementation on Feed Efficiency and Profitability of Dairy Systems. J. Dairy Sci. 87:2902-2911.

Van Soest, P.J., J.B. Robertson, and B.A. Lewis. 1991. Methods for dietary fiber, neutral detergent fiber and non-starch polysaccharides in relation to animal nutrition. J. Dairy Sci. 74:3583-3597. 